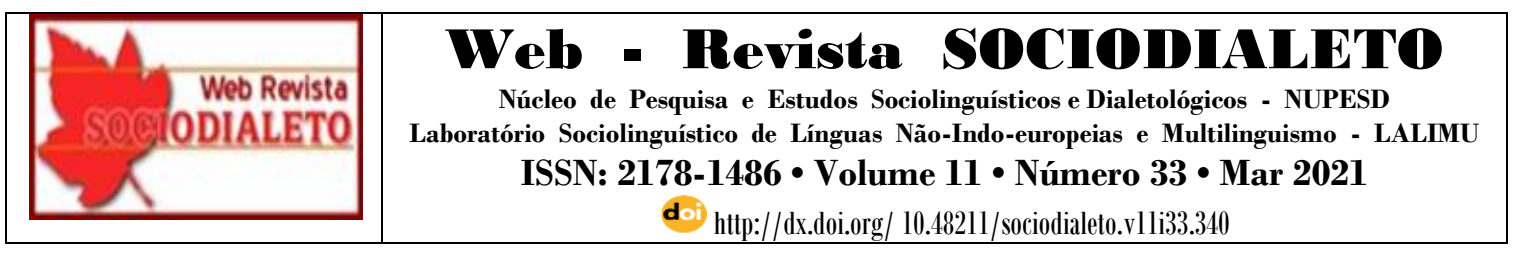

\title{
A REDUÇÃO DOS DITONGOS NASAIS ÁTONOS EM CACHOEIRINHA - PE
}

THE REDUCTION OF UNSTRESSED NASAL DIPHTHONGS IN CACHOEIRINHA - PE

\author{
Sabrina Correia Medeiros (Uniasselvi/ UFPE) ${ }^{1}$ \\ sabrina_medeiros2011@ @otmail.com \\ Lídia Nadine Bezerra Braga (Uniasselvi/ UFPE)² \\ nadinebbraga2015@gmail.com \\ Fernando Augusto de Lima Oliveira (UPE) ${ }^{3}$ \\ fernando.oliveira@upe.br
}

\begin{abstract}
RESUMO: Esta pesquisa tem como finalidade analisar o processo de nasalização e desnasalização presente em final de vocábulos e a redução ou não dos ditongos nasais átonos na comunidade de fala de Cachoeirinha - PE, analisando quais condicionantes linguísticos e extralinguísticos contribuem para a ocorrência da variante. Para tanto, nosso estudo está embasado dentro da perspectiva teóricometodológica da Teoria da Variação Linguística, de Labov (2008 [1972]), e para o embasamento sociofonético os teóricos Leda Bisol (2001), Elisa Battisti (1997, 2000, 2002, 2003) e Schwindt e Bopp (2009). Para análise todas as ocorrências coletadas foram codificadas no software computacional Goldvarb X (2005), um programa de análise estatística e probabilística, para que fossem apresentados os valores de frequência da variante e seu peso relativo. À medida que os homens desnasalizam o ditongo mais que as mulheres, os mais jovens aplicam menos o fenômeno e a segunda faixa etária é propensa a reduzir o ditongo átono nasal, em relação à escolaridade a hipótese sociolinguística foi confirmada indicando que os menos escolarizados tendem a reduzir, acerca da única variável que foi tida como significativa, contexto fonológico precedente, a consoante nasal favorece a redução enquanto o onset vazio mantém o ditongo. Defendemos que a pesquisa em tela corrobora para a descrição do perfil sociolinguístico dessa comunidade de fala e para o estudo de variantes sociofonéticas em Pernambuco e no Nordeste.
\end{abstract}

PALAVRAS-CHAVE: Sociolinguística, Sociofonética, Desnasalização, Teoria da Variação, Ditongo Nasal Átono.

ABSTRACT: This research aims at analyzing the nasalization and desnasalization process present at the end of words and the reduction or not of the unstressed nasal diphthongs in the speech community of Cachoeirinha - PE, analyzing which linguistic and extralinguistic factors contribute to the occurrence of the variant. For this, our study is based on the theoretical-methodological perspective of Labov's Theory of Linguistic Variation (2008 [1972]), and for the sociophonectical basis the theorists Leda Bisol (2001), Elisa Battisti (1997, 2000, 2002, 2003) and Schwindt and Bopp (2009). For analysis, all occurrences were coded in the software Goldvarb X (2005), a program of statistical and probabilistic analysis, so that the

\footnotetext{
${ }^{1}$ Pós-graduada em Metodologia da Língua Portuguesa e Literatura - Uniasselvi / GEADLin - Garanhuns - UPE.

${ }^{2}$ Mestranda em Linguística - UFPE - Recife/ GEADLin - Garanhuns - UPE.

${ }^{3}$ Prof. Dr. do curso de Licenciatura em Letras: Língua Portuguesa e suas Literaturas - UPE. Líder do GEADLin/ UPE - Garanhuns - PE.
} 
frequency values of the variant and its relative weight were presented. As men desnasalize the diphthong more than women, younger people apply less phenomena and the second age group is prone to reduce the nasal diphthong, in relation to schooling the sociolinguistic hypothesis was confirmed indicating that the less educated tend to reduce, about the only variable that was considered as a significant previous phonological context, the nasal consonant favors the reduction while the empty onset maintains the diphthong. We argue that the screen search corroborates the description of the sociolinguistic profile of this speech community and the study of sociophonic variants in Pernambuco and Northeast.

KEYWORDS: Sociolinguistic, Sociophonetica, Desnasalization, Theory of Linguistic Variation, Unstressed Nasal Diphthongs.

\section{Introdução}

A Sociolinguística Variacionista surgiu em 1964 e oficializou-se como ciência em 1972 com a publicação do livro "Padrões Sociolinguísticos" de William Labov, com o propósito de estudar os traços linguísticos contidos nas variações, tendo a língua como sistema heterogêneo, passível da influência dos elementos linguísticos e dos aspectos sociais próprios das interações sociais e das situações de uso dos falantes integrantes de uma determinada Comunidade de Fala.

Com isso, a Teoria da Variação Linguística, vertente de cunho teóricometodológico, traz contribuições significativas com base nas discussões a partir dos elementos que levam a mudança, considerando não só os elementos internos da língua, mas também os elementos originários do âmbito social, dos fatos e das interações, ao analisar, assim, a heterogeneidade e as condições que levam à mudança e à variação, tendo prioridade, primeiramente, os fatores sociais sobre os fatores internos da estrutura da língua. A esse aspecto, e Labov (1972 [2008] p. 238) destaca: “[...] se não houvesse necessidade de contrastar este trabalho com o estudo da língua fora de seu contexto social, eu preferiria dizer que se trata simplesmente da linguística”.

Dentre as variações contidas na Língua Portuguesa, há os fenômenos de nasalidade em estruturas fonético-fonológicas, em que se manifestam nos seguintes contextos:

(1) vogal seguida de nasal na mesma sílaba no interior do vocábulo, apresentando a chamada "vogal nasal" pelo seu valor contrastivo; 
a. pança, fenda, monge, longe, panda

(2) vogal seguida de nasal na sílaba seguinte no interior do vocábulo, em que a nasalidade é apresentada pela vogal é alofônica, originando assim a "vogal nasalizada";

a. cama, cana, goma, puma, lona

(3) vogal seguida de nasal em final de vocábulo, dando origem ao "ditongo nasal" e ao "monotongo nasal"4 que podem ser tônicos ou átonos;

Dentre os ditongos tônicos temos como exemplos;

4) leitão, farpão

Dentre os ditongos átonos temos;

5) órgão, sótão

Entre os monotongos tônicos temos;

6) convém, também

E dentre os monotongos átonos temos:

7) jovem, garagem

Na possibilidade (5 - monotongos átonos), é necessário esclarecer-se que são monotongos apenas ortograficamente, porém em sua transcrição fonética apresentam-se ditongados. Podemos tomar como exemplo o vocábulo jovem que foneticamente, apresenta-se da seguinte forma ['3əvẽ̃n $]^{5}$. Com isso podemos considerar o ditongo /ẽ̃/ presente nele. Porém é importante ressaltar que monotongos terminados em "an" não podem ser ditongados.

Dentre as possibilidades de variação em estruturas fonético-fonológicas, este trabalho focalizará, apenas, os fenômenos de (5 - ditongos átonos) e (7 - monotongos

\footnotetext{
${ }^{4}$ Neste momento da pesquisa me refiro a monotongos nasais ortograficamente, não me refiro a aspectos fonético-fonológicos.

${ }^{5}$ A partir desta colocação todas as palavras que apresentarem o fenômeno estudado presentará ao lado a transcrição fonética.
} 
átonos ortograficamente que podem ser ditongados), em contextos de vogal seguida de nasal em final de vocábulo; observando, assim, o processo de desnasalização e redução do ditongo nasal e dos monotongos que podem ser ditongados foneticamente, doravante ditongos nasais átonos, quando incluídos no contexto de uso na Comunidade de Fala de Cachoeirinha-PE.

Desse modo, é possível observarmos o contraste entre a forma padrão e a fala informal muito recorrente em Cachoeirinha-PE, em ditongos nasais átonos nas seguintes frases:

(1) [...] eles não iam ['iãw] assaltar a gente [...] (CAAM. L3. 1112. p.11)

(2) [...] a origi [o'rizi] foi justamente por causa da... a renda da cidade que é couro e aço [...] (MEMS. L9. 154 e 55. p.53)

Analisando as sentenças supracitadas, é possível verificar que na sentença de (1) o ditongo está sendo mantido em /ãw/ correspondendo a variedade padrão e apresentando o fenômeno da nasalização; e em (2), podemos notar que o ditongo /ẽI / foi reduzido para apenas uma vogal oral /i/ sendo, dessa forma, a forma não-padrão evidenciando o processo de desnasalização.

Com vista na percepção dessa variação linguística em Pernambuco, mais exatamente em Cachoeirinha-PE e a carência dos estudos de redução e desnasalização dos ditongos átonos na região, parece-nos importante se fazer um estudo sistemático e descritivo dessa variante de dados de fala com base nos parâmetros de Labov (1972 [2008] p. 236-239). Com isso, a pesquisa se centrará na coleta de entrevistas de 36 entrevistados em que consideraremos três variáveis extralinguísticas: sexo (homem, mulher), idade (15 a 61 anos) e escolaridade (médio, superior); e três variáveis linguísticas: contexto fonológico precedente (nasal, não-nasal, onset vazio), contexto 
fonológico seguinte (nasal, não-nasal, vogal) e classe de palavra (verbo, substantivo, advérbio, adjetivo).

\section{Arcabouço Fonético-fonológico em Relação aos Ditongos Nasais Átonos}

Dentre os trabalhos de cunho fonológico para estudo dos ditongos nasais átonos e o processo de desnasalização em postônicas finais encontramos embasamento nas teorias postuladas pela Fonologia Gerativa Padrão introduzida por Chomsky e Halle (1968, p. 190 apud. SILVA, 2017), defendendo os sons como elementos inatos sendo que a fala é gerada por processos originados de representações subjacentes, considerando os conceitos de competência e desempenho, porém o desempenho se associa à fala, já a competência a estrutura da língua.

Outro aspecto a se considerar se refere às oposições e distribuições presentes nos sistemas sonoros. Inspirados nesse modelo teórico, Prince e Smolensky criaram a Optimality Theory que foi traduzido para o português como Teoria da Otimidade por Battisti (1998, p. 217, SILVA, 2017) e Teoria de Otimalidade (1999, p. 217, SILVA, 2017), buscando padrões comuns nas línguas e limites contidos nas variações das línguas naturais. Essa Teoria da Otimalidade se baseia nas análises de input e output em que são examinadas restrições possíveis, sendo que podem ser violadas, porém de forma mínima. Para isso o gerador $\mathrm{GEN}^{6}$ cria um conjuntos potenciais para a saída ótima, fazendo parte do input, e o $\mathrm{EVAL}^{7}$ seleciona a melhor escolha para saída, ou output. Analisando-se por esse viés através de elementos prosódicos, defende-se que a redução do ditongo nasal átono acontece porque a sílaba pesada ${ }^{8}$ não é acentuada, originando diversas variações possíveis.

\footnotetext{
${ }^{6}$ Para um dado input, o gerador GEN cria um conjunto de candidatos potenciais para a saída (SILVA, 2017).

${ }^{7}$ Para cada um dos candidatos, o avaliador EVAL seleciona a melhor (ótimo) saída (output) para a entrada (input) dada (SILVA, 2017)

${ }^{8}$ De acordo com Fonologia Métrica diz respeito à sílaba que tem duas ou mais posições associadas à língua, geralmente seu núcleo é ramificado (contendo ditongos ou vogais longas) ou o núcleo é seguido de consoante. (SILVA, 2017)
} 
Nesses estudos podemos encontrar as denominações de Nonfinality que se concentra em nunca acentuar a última sílaba da palavra, o que acontece nos vocábulos aqui estudados, já que possuem suas sílabas finais átonas, porém há uma violação da restrição de Edgemost $^{9}$ que é oposta ao Nonfinality ${ }^{10}$ em que a regra centraliza o acento na extremidade da palavra, consequentemente a última sílaba, por isso a desnasalização torna-se possível para melhor formação do pé prosódico. De acordo com os estudos de Battisti, por meio da prosódia, foi feita a seguinte análise contendo as seguintes opções pelo GEN em seu input:

1) '3ó . vẽI

2) 'zóvi

3) '3ว(vẽI’)

Analisando as opções supracitadas, a alternativa 1 se mostra como pior opção para escolha, visto que possui sílaba pesada e acentuada no final do vocábulo. Diante das escolhas dadas, a que possui melhores condições prosódicas para output seria a opção 2 , em que a mora ${ }^{11}$ (que pode ser representada por $\mathrm{N}$ ) e a consoante subjacente não são postas $<_{I}>$, constituindo uma melhor formação do troqueu ${ }^{12}$ sendo bimoraico e se posicionando melhor que um trimoraico. Além disso, podemos retornar às regras de Nonfinally e Edgemost notando que este exemplo viola as duas, possibilitando uma melhor opção para pronúncia no falar coloquial, não possuindo pé e nem pico no final da sílaba. Já a opção 3) não pode ser escolhida devido à dupla violação do Nonfinally, apresentando o pico e o pé em sílaba final.

\footnotetext{
${ }^{9}$ Significa "mais à beira", que demanda que o acento se posicione na última sílaba. (BATTISTI, 1997)

${ }^{10}$ Nonfinality é uma restrição específica de acento. Ela é responsável por um padrão bastante geral nas línguas, o de evitar acento em sílaba final de vocábulo. (BATTISTI, 1997)

${ }^{11}$ Constituintes ou unidades que constituem a sílaba, desse modo uma sílaba pesada consiste em duas moras, enquanto a sílaba leve consiste uma mora segundo Hyman (1985, p. 96, apud. COLLISCHONN, 2001)

${ }^{12}$ Ele pode se apresentar de duas formas, sendo assim o troqueu mórico e o silábico. O troqueu considera o peso silábico, ou seja, contando as moras (unidades de tempos em que as sílabas são constituídas), cada duas moras formam o pé. Enquanto o troqueu silábico se constitui através de pé dissílabo com proeminência, que conta sílabas e ignora a estrutura interna (COLLISCHONN, 2001, p. 130).
} 
Dessa forma, foi comprovado que a redução dos ditongos nasais átonos é de condicionamento prosódico fazendo parte da estruturação rítmica das línguas, sendo assim melhor escolha para output.

Collischonn (COLLISHONN, 2007) complementa esse processo com o aspecto de proeminência acentual em relação à estrutura, em que um padrão de acento marcado se torna um padrão não-marcado, ou seja, de um pé excepcional para um pé troqueu, o qual ocorre com também com os ditongos nasais finais, tornando as paroxítonas marcadas em não-marcadas. Lee (LEE, 2007) postula sobre o Encurtamento Iâmbico que pode ser associado ao fenômeno aqui investigado, a qual defende que quando a última sílaba é pesada e não atrai acento sofre redução sendo precedida por uma sílaba leve ${ }^{13}$ tônica.

Outro processo que pode ser citado é a sobre a redução vocálica citada por Major e descrita por Hajek (1997, p. 354, apud. BATTISTI, 2003) de forma que as sílabas postônicas possuem menor peso silábico possibilitando a redução vocálica.

Já Bisol (1989, p. 257, apud. BATTISTI, 2000) atribui a redução a não marcação de classe em vocábulos como ontem, garagem, dentre outros, originando um ditongo próprio do processo de assimilação sendo um espraiamento na consoante presente na coda, sendo um ditongo derivado ("ou monotongo ditongado" no nível póslexical) ocasionando a possível redução.

\section{História dos ditongos nasais}

Aos fazermos um estudo diacrônico da variante examinada podemos notar que os ditongos nasais não são comuns dentre as línguas do mundo, dentre as línguas românicas apenas são contidos no francês e no português (CHAVES, 2017). Com isso Sampson (1999, p. 44, apud. CHAVES, 2017) traz a seguinte proposição: "Como as vogais nasais representam tipos de vogais especiais e complexas, elas podem ser vistas

\footnotetext{
${ }^{13}$ De acordo com a Fonologia Métrica, a sílaba leve tem uma única posição esqueletal associada à rima.
} 
como inerentemente menos estáveis, de modo que a tendência para eliminá-las é compreensível".

Com isso, segundo Donato, não é comprovada a presença de vogais e ditongos nasais no latim, apenas sua introdução a partir dos suevos, em que senhores de Lisboa e Minho dos anos 405 e 585 utilizavam o ditongo -ão (1993, p. 184, apud, BATTISTI, 2002). De acordo Williams também atribuem seu surgimento devido ao uso contínuo de consoantes nasais pelos celtas (1993, p. 184, apud, BATTISTI, 2002).

Segundo Williams (1962, p. 45, apud. CHAVES, 2017) ao decorrer dos anos, ocorreram processos de redução nas palavras, de modo que intervocálicos como /N/ nasalizaram a vogal anterior e o reduziram, expandindo para nasalidade para a vogal seguinte. Depois, houve mais supressões de forma que se o contexto nasal se localizasse entre a penúltima vogal tônica e a última vogal átona, estas sílabas se tornariam um ditongo nasal, se apresentando da seguinte forma: germanum - irmãa $(1973$, p. 184, apud. BATTISTI, 2002). Porém, um fator importante e interessante se estruturava quando o intervocálico /n/ se localizava entre postônicas penúltimas e finais: homine homẽe - homẽ ou home. Dessa forma, podemos notar que a desnasalização é provinda de elementos inerentes à língua.

Martins (1995, p. 185, apud. BATTISTI, 2002) afirma que historicamente há uma relação de interdependência entre ditongação e atonicidade, observando a redução diacrônica em situação átona. Dessa forma, a terminação arcaica <om> quando tônica evoluiu para <ão> (associamos a manutenção aos vocábulos que atualmente mantém o ditongo átono nasal) e quando átona se transformou em $<\mathbf{u m}>$ ou $<\hat{\mathbf{o}}>$ se apresentada da seguinte forma: fôrum ou fôro.

Também pode se observar a tendência à queda da nasalidade vocálica em final de palavra. Para Nunes (1969):

As vogais nasais procedem em geral de vogais puras que tomaram [...] a nasalidade de $\mathrm{m}$ ou $\mathrm{n}$, desaparecendo a articulação destas consoantes. Observa-se o fenômeno nos monossílabos [...] cum (com), sum (som), mas não se verifica na maior parte dos vocábulos que na língua-mãe se escreviam com m terminal, porquanto, para tais casos já 
se havia dado a redução da pronúncia da consoante final. (NUNES, 1969, p. 45-46, apud. CHAVES, 2017)

Dessa forma, podemos verificar que o surgimento da desnasalização em vogais postônicas também se confirma em âmbitos diacrônicos, verificando que este fenômeno faz parte da língua desde seus primórdios e sua raiz que resulta na redução que se origina do selta, do suevo e do latim posteriormente.

Portanto, verificamos que a variante também possui traços e tendências provenientes da língua, constatando isso através dos estudos fonético-fonológicos e diacrônicos, averiguando que a estrutura a qual foi constituída a língua proporciona e condiciona o acontecimento do fenômeno.

\section{Metodologia}

Para o aparato metodológico, a pesquisa foi constituída a partir dos recortes de falas provenientes de questionamentos feitos a 36 informantes da comunidade de fala de Cachoeirinha - PE e que não mantiveram contato com outra comunidade de fala por 10 anos. Dessa forma, foram selecionadas as seguintes variáveis extralinguísticas e linguísticas para análise as ocorrências obtidas:

Tabela 1. Variáveis consideradas na análise

(com os respectivos símbolos utilizados na codificação)

\begin{tabular}{|l|l|}
\hline Variáveis Extralinguísticas (externas) & Variáveis Linguísticas (internas) \\
\hline Sexo & Contexto Fonológico Precedente \\
$\mathrm{h}-$ Homem & $\mathrm{g}$ - consoante nasal - lobisomem \\
$\mathrm{m}-$ Mulher & $\mathrm{j}$ - consoante não-nasal - jovem \\
& $\mathrm{o}$ - onset vazio - queriam \\
\hline Idade & Contexto Fonológico Seguinte \\
$\mathrm{k}-15-30$ anos & $\mathrm{a}$ - consoante nasal - falaram nada \\
$1-31-46$ anos & $\mathrm{n}$ - consoante não-nasal - perderam valor \\
$\mathrm{b}-47-61$ anos & $\mathrm{d}$ - vogal - porcentagem equivalente \\
& $\mathrm{f}$ - sem ocorrência do contexto fonológico seguinte \\
\hline Escolaridade & Classe de palavras \\
\hline
\end{tabular}




\begin{tabular}{|c|c|}
\hline $\begin{array}{l}\text { Web Revista } \\
\text { ODIALETO }\end{array}$ & $\begin{array}{c}\text { Núcleo de Pesquisa e Estudos Sociolinguísticos e Dialetológicos - NUPESD } \\
\text { Laboratório Sociolinguístico de Línguas Não-Indo-europeias e Multilinguismo - LALIMU } \\
\text { ISSN: 2178-1486 • Volume } 11 \bullet \text { Número } 33 \bullet \text { Mar 2021 } \\
\text { doi http://dx.doi.org/ } 10.48211 / \text { sociodialeto.vlli33.340 }\end{array}$ \\
\hline
\end{tabular}

\begin{tabular}{|l|l|}
\hline $\mathrm{c}-$ Ensino Médio & $\mathrm{t}-$ substantivo \\
$\mathrm{s}-$ Ensino Superior & $\mathrm{v}-$ verbo \\
& $\mathrm{w}-$ advérbio \\
& $\mathrm{i}-$ adjetivo \\
\hline
\end{tabular}

Foram feitas entrevistas em gravadores digitais de 7 a 33 minutos, a partir de temáticas do cotidiano e da sociedade correspondente à comunidade de fala de Cachoeirinha - PE, para proporcionar a descontração e espontaneidade nas respostas obtidas, tendo como intuito a observação, descrição e análise desses recortes de fala com base nas variáveis linguísticas supracitadas, a fim de verificarmos a presença ou não da redução dos ditongos nasais átonos. Utilizamos o seguinte guia de perguntas:

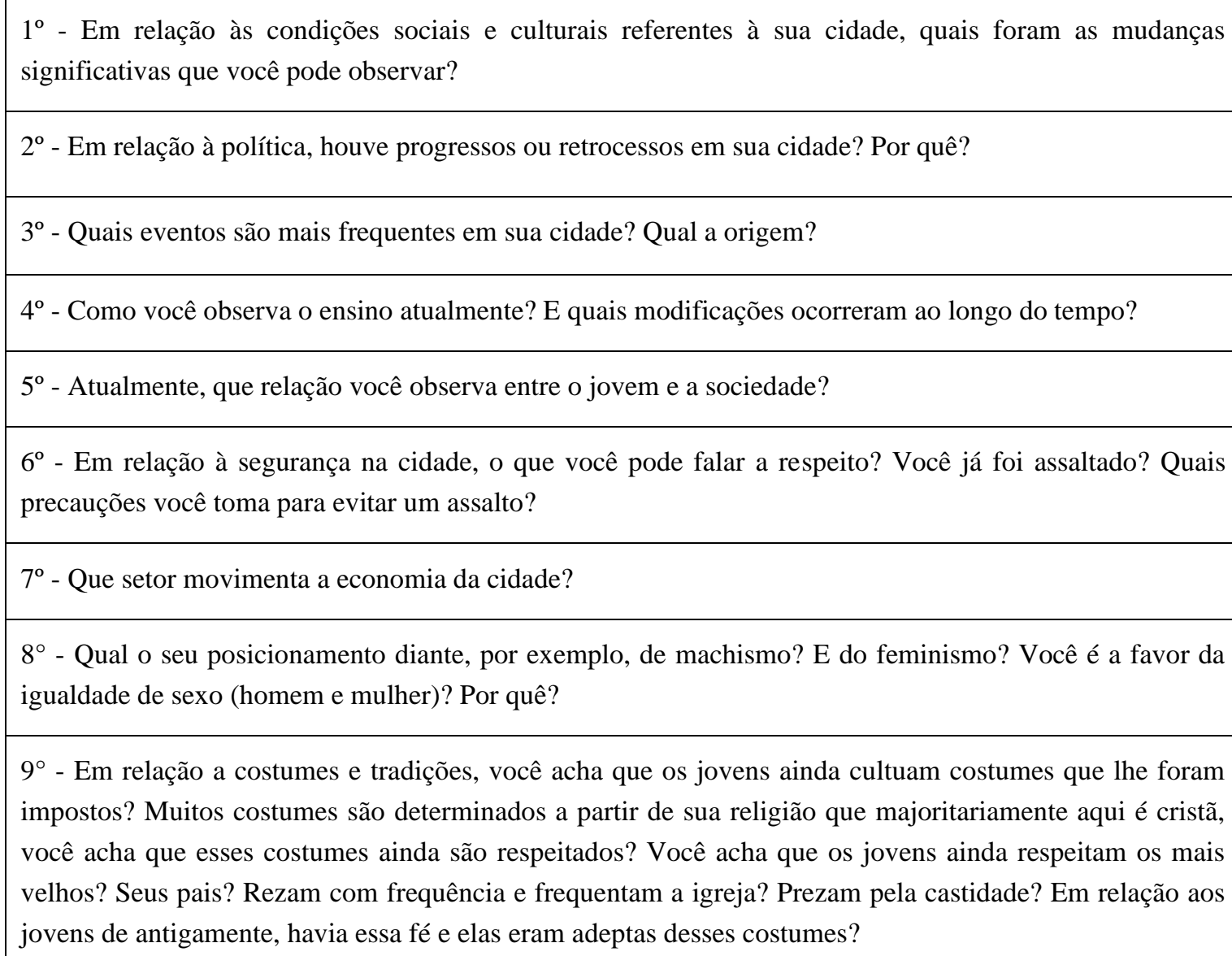

FONTE: elaborado pela pesquisadora. 
Além das perguntas feitas foram mostradas imagens que persuadissem os entrevistados a falarem as palavras que possuem o fenômeno examinado.

É relevante ressaltar que para a escolha das perguntas pertencentes ao questionário é preciso entender o contexto da comunidade de fala, que aqui se direciona à cidade de Cachoeirinha - PE. Outro ponto importante a ser lembrado é que a pesquisa de campo não foi feita no distrito de Cabanas; dessa forma, não abrangendo essa região, apenas os distritos sede.

As entrevistas foram transcritas manualmente a partir da transcrição mista, visto que é um fenômeno fonético-fonológico. Sendo assim, transcritas ortograficamente e ao lado das palavras que contém a variante estudada fizemos a transcrição fonética, com base no alfabeto internacional de fonética proposta pelo IPA (International Phonetic Alphabet), referenciado nacionalmente pela sigla AFI (Alfabeto Fonético Internacional) (SILVA, 2017, p. 40).

\section{Análise dos Dados}

Este capítulo tem como propósito fazer a análise dos dados obtidos apresentando os pesos relativos e termos percentuais, de forma que a aplicação da regra se refere à manutenção do ditongo átono nasal, ou seja, a norma padrão.

A análise será discorrida em tópicos, tabelas e gráficos para melhor visualização, de acordo com a sequência das variáveis que foram apontadas como significativas pelo software computacional Goldvarb X (2005), os dados foram rodados de 1 para 2, de forma que 1 seria a norma padrão (a manutenção do ditongo átono nasal ou a nasalização) e o 2 a norma não-padrão (a redução do ditongo átono nasal ou a desnasalização).

Dessa forma, todas as ocorrências coletadas foram rodadas no programa, sendo apresentados no Gráfico 1 os seguintes valores para nasalização (manutenção do ditongo átono nasal) e desnasalização (redução do ditongo átono nasal): 


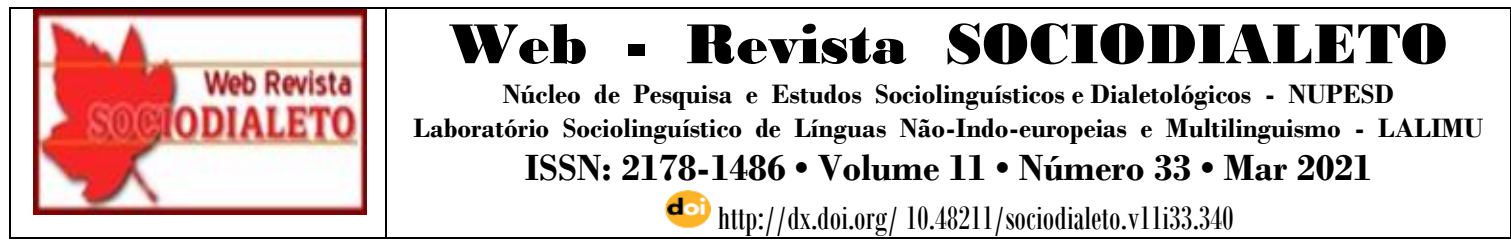

Gráfico 1 - Distribuição das ocorrências das variantes nasalização e desnasalização

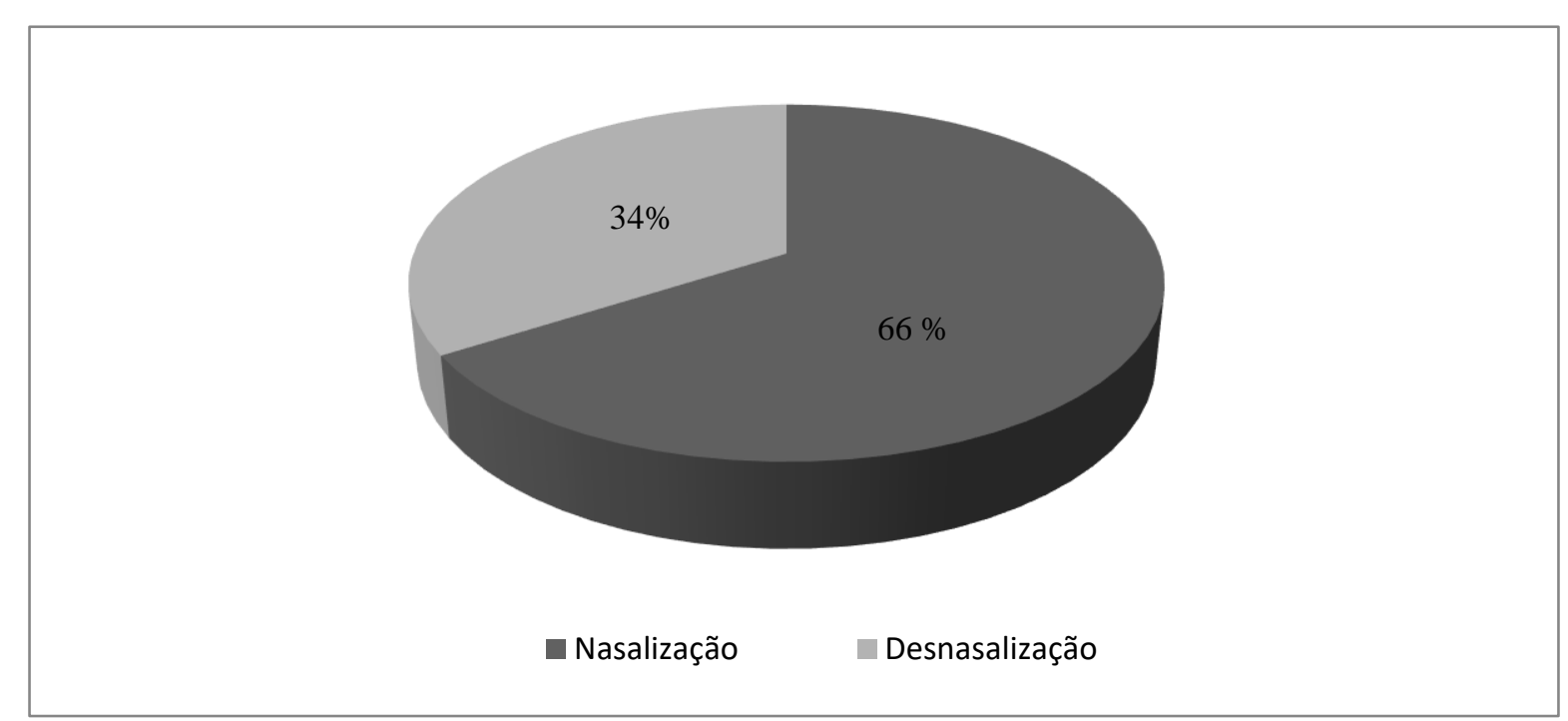

FONTE: elaborado pela autora.

Desse modo, podemos observar que os cachoeirinhenses em seu perfil linguístico optam e utilizam mais a manutenção da nasalização, ou seja, o ditongo átono nasal é conservado.

Com o percentual de $66 \%$ correspondendo a 1222 ocorrências e $34 \%$ correspondendo a 631 ocorrências podemos perceber que se predomina a conservação do ditongo átono nasal com uma grande diferença com base nos recortes retirados das entrevistas feitas pela cidade em análise.

A seguir podemos conferir recortes tirados do corpus que podem embasar os dados registrados:

(1) Mas eles tinham ['tĩnãw] vergonha de mostrar. (RHS. L12. 1145. p.79)

(2) Antigamente eu acho que respeitavam [hesper̃’tavãw] mais. (ECSO. L13. 1103. p.84)

(3) Tinha a a... as de rua que o povo se reuniam, formavam comissão, faziam [fa'ziãw] a festa profana. (JSB. L15. 143 e 44. p.96) 
(4) É um grupo de mulheres que se adequam [a'dekwãw] ao movimento de ser feminista. (LLS. L22. 1202 e 203. p.146)

(5) O homem ['õmẽın] trai ele torna-se... galã no no popular. (MAS. L24. 1111. p.159)

Desse modo, podemos constatar que os resultados não coincidem com os estudos feitos pela maioria dos autores citados, em que muitos comprovam a predominância da redução do ditongo átono nasal. Dentre esses, podemos citar Silva (2016) que concentrou sua pesquisa no Quilombo do Curiaú no Amapá, e constatou que $77 \%$ dos falantes desnasalizaram o ditongo átono nasal.

Nos estudos de Battisti de 2000 acusou-se que a redução do ditongo nasal predomina em seus estudos com $43 \%$ das ocorrências voltadas para aa desnasalização, porém nos estudos de 2003 já obteve-se uma ocorrência moderada do fenômeno.

Nos estudos realizados por Mendonça, Dias e Oliveira (2017) foi comprovado que $63 \%$ dos ditongos átonos nasais foram monotongados, uma frequência ainda maior em relação a outros estudos.

\section{Variáveis relevantes para a redução dos ditongos átonos nasais}

A seguir iremos verificar quais variáveis influenciaram na redução dos ditongos nasais átonos, sua desnasalização e monotongação, é importante salientarmos que todas as ocorrências foram rodadas no Goldvarb X (2005) para a amostragem dos termos percentuais e dos pesos relativos. Antes de começarmos a análise é necessário frisar que na variável Classe de palavras, os advérbios foram retirados, visto que só houveram duas ocorrências sendo todas nasalizadas, ou seja, mantendo a norma padrão.

Abaixo, segue a ordem das variáveis que foram consideradas estatisticamente significativas para a supressão do ditongo nasal átono.

Tabela 2 - Ordem dos grupos de fatores considerados estatisticamente significativos para a redução dos ditongos átonos nasais

\begin{tabular}{|l|rr|}
\hline 1. & $\begin{array}{r}\text { Idade } \\
\end{array}$ & \\
& $\bullet$ & $15-30$ anos; \\
\hline
\end{tabular}




\begin{tabular}{|c|c|}
\hline $\begin{array}{l}\text { Web Revista } \\
\text { ODIALETO }\end{array}$ & 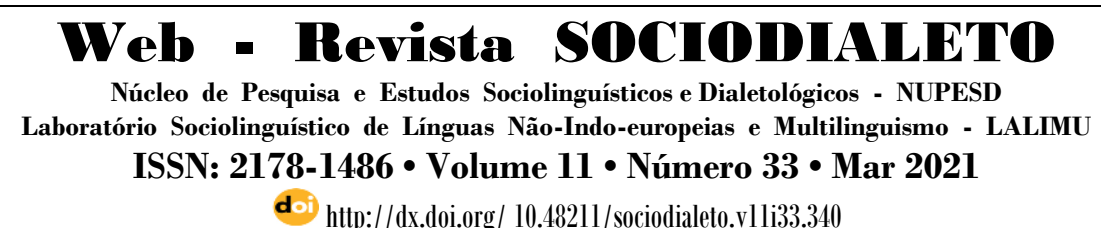 \\
\hline
\end{tabular}

\begin{tabular}{|c|c|}
\hline & $\begin{array}{l}\text { - } \quad 31-46 \text { anos; } \\
\text { - } \quad 47-61 \text { anos. }\end{array}$ \\
\hline 2. & $\begin{array}{l}\text { Contexto Fonológico Precedente } \\
\text { - Consoante nasal } \\
\text { - Consoante não-nasal } \\
\text { - Onset vazio }\end{array}$ \\
\hline 3. & $\begin{array}{l}\text { Escolaridade } \\
\text { - Ensino Médio; } \\
\text { - Ensino Superior. }\end{array}$ \\
\hline 4. & $\begin{aligned} \text { Sexo } & \\
\text { - } & \text { Homem; } \\
\text { - } & \text { Mulher. }\end{aligned}$ \\
\hline
\end{tabular}

FONTE: elaborado pela autora.

\subsection{A influência da variável Idade na redução dos ditongos átonos nasais}

A variável Idade foi a primeira a ser selecionada quanto relevante no estudo da pesquisa, apresentando os seguintes valores que podem ser mais bem visualizados no gráfico:

Gráfico 2 - Influência da Variável Idade na Escolha da Manutenção do Ditongo Nasal Átono

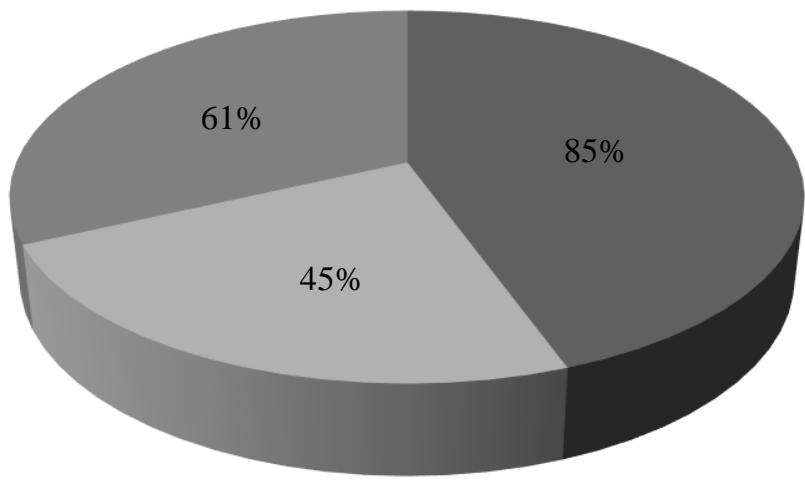

15-30 anos - 31-46 anos $\quad$ 47-61 anos

FONTE: elaborado pela autora. 


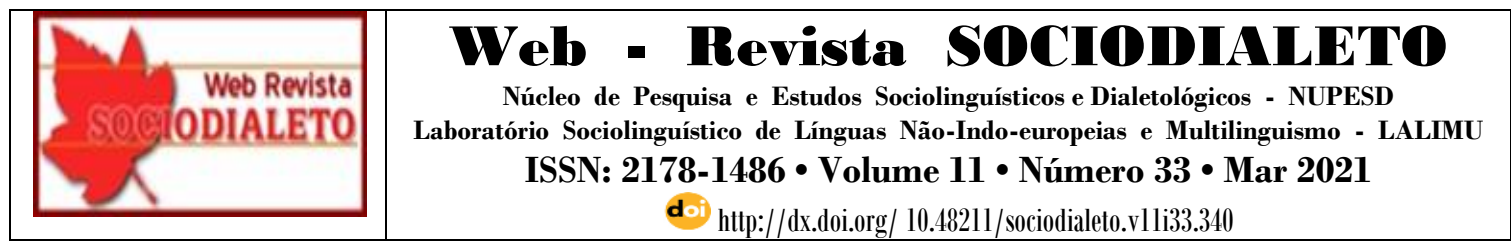

Como podemos observar os mais indivíduos mais novos na faixa etária de 15-30 anos prezam pela norma padronizada e por manter a nasalidade dos ditongos, ao passo que a idade intermediária opta mais pela não-padrão reduzindo o ditongo átono nasal.

Tabela 3

Influência da Variável Idade na Escolha da Manutenção do Ditongo Nasal Átono

\begin{tabular}{|l|l|l|l|}
\hline IDADE & Aplic./ Total & $\%$ & Peso Relativo \\
\hline $15-30$ anos & $641 / 758$ & $85 \%$ & .73 \\
\hline $31-46$ anos & $248 / 546$ & $46 \%$ & .26 \\
\hline $47-61$ anos & $333 / 549$ & $61 \%$ & .42 \\
\hline
\end{tabular}

Input: 0.688

Significância: 0.067

Podemos perceber uma grande disparidade entre os valores apresentados de forma que a primeira faixa etária (15-30 anos) e a segunda (31-46 anos) apresentando respectivamente .73 indicando 641 ocorrências de 758, e .26 indicando 248 ocorrências de 546, constatando que as pessoas entre 15 e 30 anos mantém o ditongo nasal átono, ou seja, a nasalização, e as pessoas entre 31 e 46 anos tendem a desnasalizar o ditongo nasal átono.

Esses dados diferem muito dos apresentados em outros trabalhos, como o de Bopp (2005) apontando que os mais jovens desnasalizam mais os ditongos que os mais velhos, sendo uma variante inovadora, diferente da situação nesta pesquisa estudada.

\subsection{A Influência da Variável Contexto Fonológico Precedente na Escolha da Manutenção do Ditongo Nasal Átono}

Conseguintemente foi apontada a variável Contexto Fonológico Precedente que apresenta os seguintes valores: 


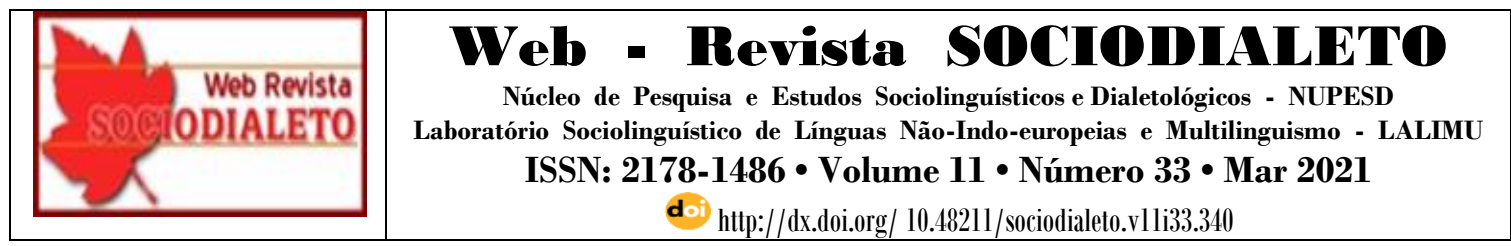

Gráfico 3 - A Influência da Variável Contexto Fonológico Precedente na Escolha da Manutenção do Ditongo Nasal Átono

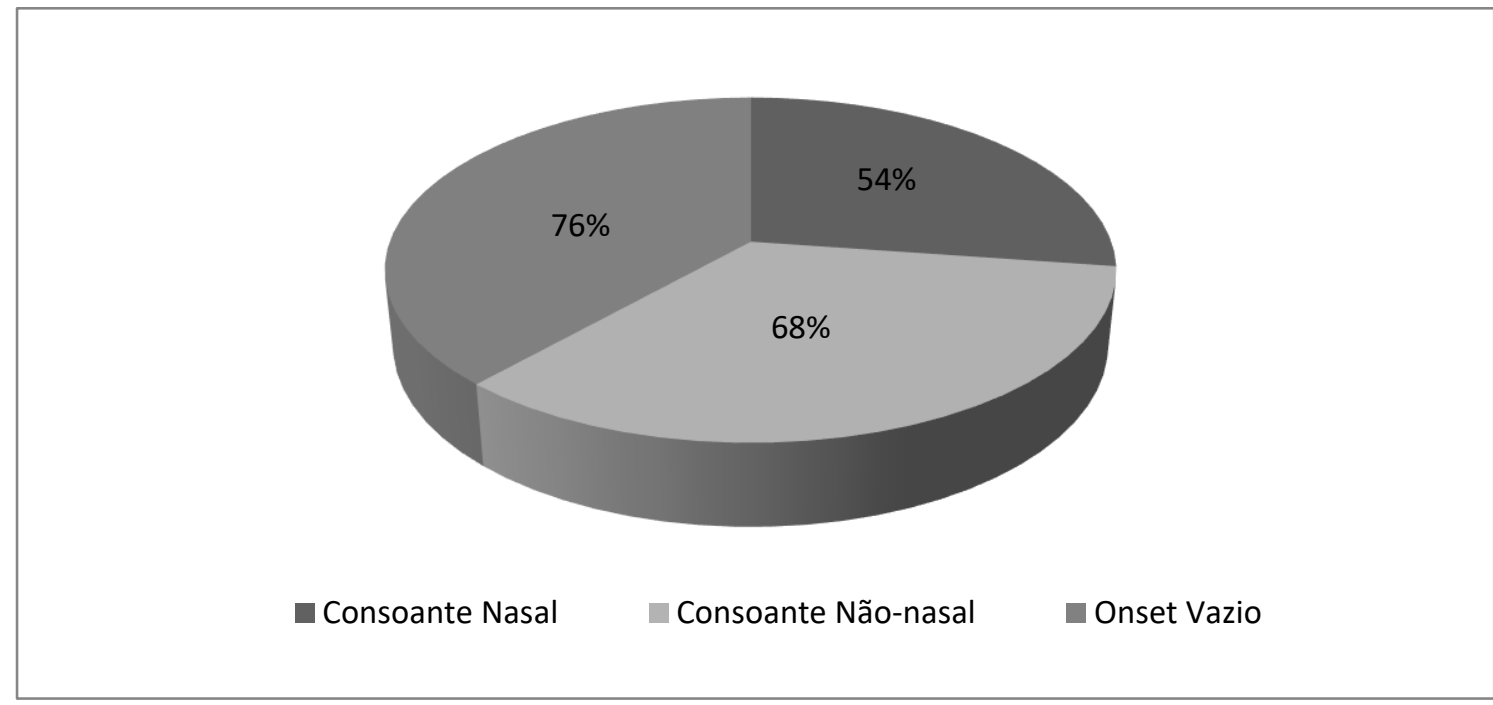

FONTE: elaborado pela autora.

Em relação ao Contexto Fonológico Precedente, acusou-se que as consoantes nasais condicionam a redução do ditongo átono nasal com $54 \%$ das ocorrências, isso pode ser explicado através da fonologia métrica, de forma que junção da presença da nasalidade do arquifonema /N/, o ditongo e o contexto precedente sendo nasal constroem uma sílaba pesada, havendo mais probabilidade de redução. Já o onset vazio (ausência de consoantes no onset) mantém a nasalização com $76 \%$ das ocorrências.

Tabela 4

\begin{tabular}{|l|l|l|l|}
\hline \multicolumn{4}{|c|}{ A Influência da Variável Contexto Fonológico Precedente na Escolha da Manutenção do Ditongo } \\
Nasal Átono \\
\hline $\begin{array}{l}\text { CONTEXTO } \\
\text { FONOLÓGICO } \\
\text { PRECEDENTE }\end{array}$ & Aplic./ Total & $\%$ & PR \\
\hline Consoante Nasal & $149 / 277$ & $54 \%$ & .35 \\
\hline Consoante Não-nasal & $1015 / 1500$ & $68 \%$ & .52 \\
\hline
\end{tabular}




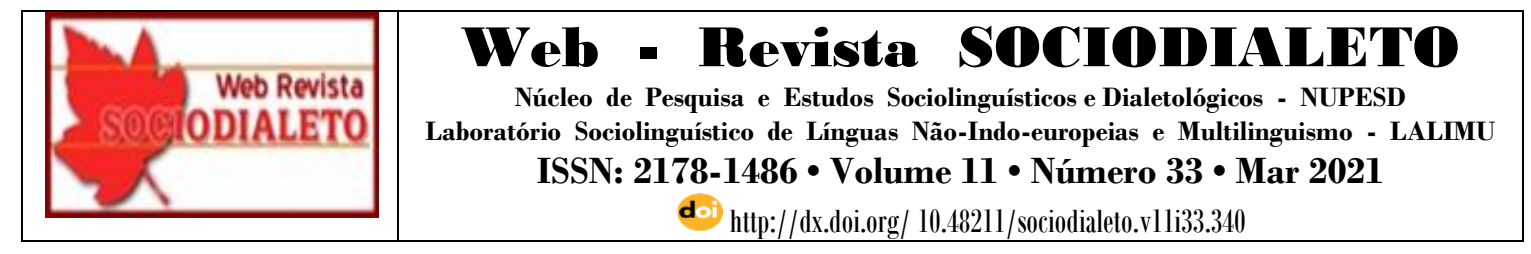

\begin{tabular}{|l|l|l|l|}
\hline Onset Vazio & $58 / 76$ & $76 \%$ & .67 \\
\hline
\end{tabular}

Input: 0.688

Significância: 0.067

Ao observamos os valores tidos acima foi registrado que o onset vazio favorece a manutenção dos ditongos átonos nasais apresentando o valor 67 com 58 ocorrências de 76, e as consoantes nasais tendem a desnasalizar os ditongos átonos com o valor .35 com 149 ocorrências de 277, também podemos notar que não há muita discrepância entre os resultados obtidos para onset vazio e consoantes não-nasais. Esta variável possui sua importância ampliada quando se revisa a literatura voltada para o estudo da desnasalização das sílabas finais e em sua maioria a variável contexto fonológico precedente não é considerada, apenas havendo estudos alegando que consoantes palatais promovem a redução do ditongo nasal átono como postula Câmara Jr. (1981, pág. 350 apud. Battisti) e Guy (1981, pág. 35 apud. De Bona \& Schwindt). Porém os resultados se igualam aos dados fornecidos por Bopp \& Schwindt em que as consoantes nasais marcam .60 favorecendo a redução do ditongo nasal átono e a ausência do onset valor a .38 para a manutenção do ditongo.

\subsection{A Influência da Variável Escolaridade na Escolha da Manutenção do Ditongo Nasal Átono}

Como terceira variante de significância foi indicada a Escolaridade apresentando os seguintes resultados: 


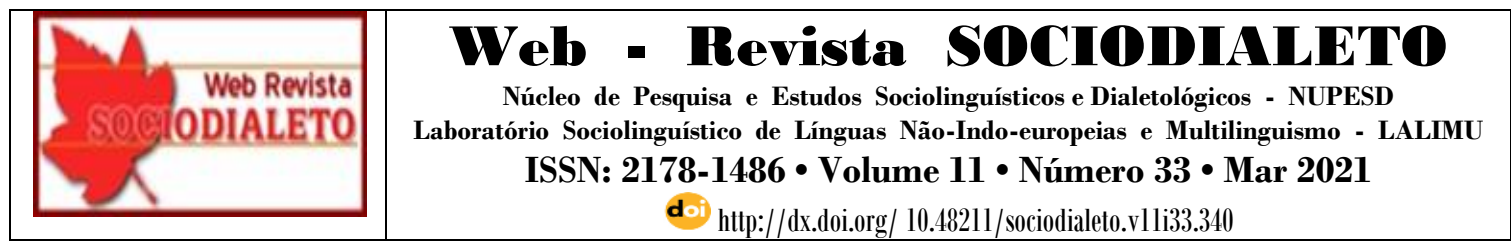

Gráfico 4 - A Influência da Variável Escolaridade na Escolha da Manutenção do Ditongo Nasal

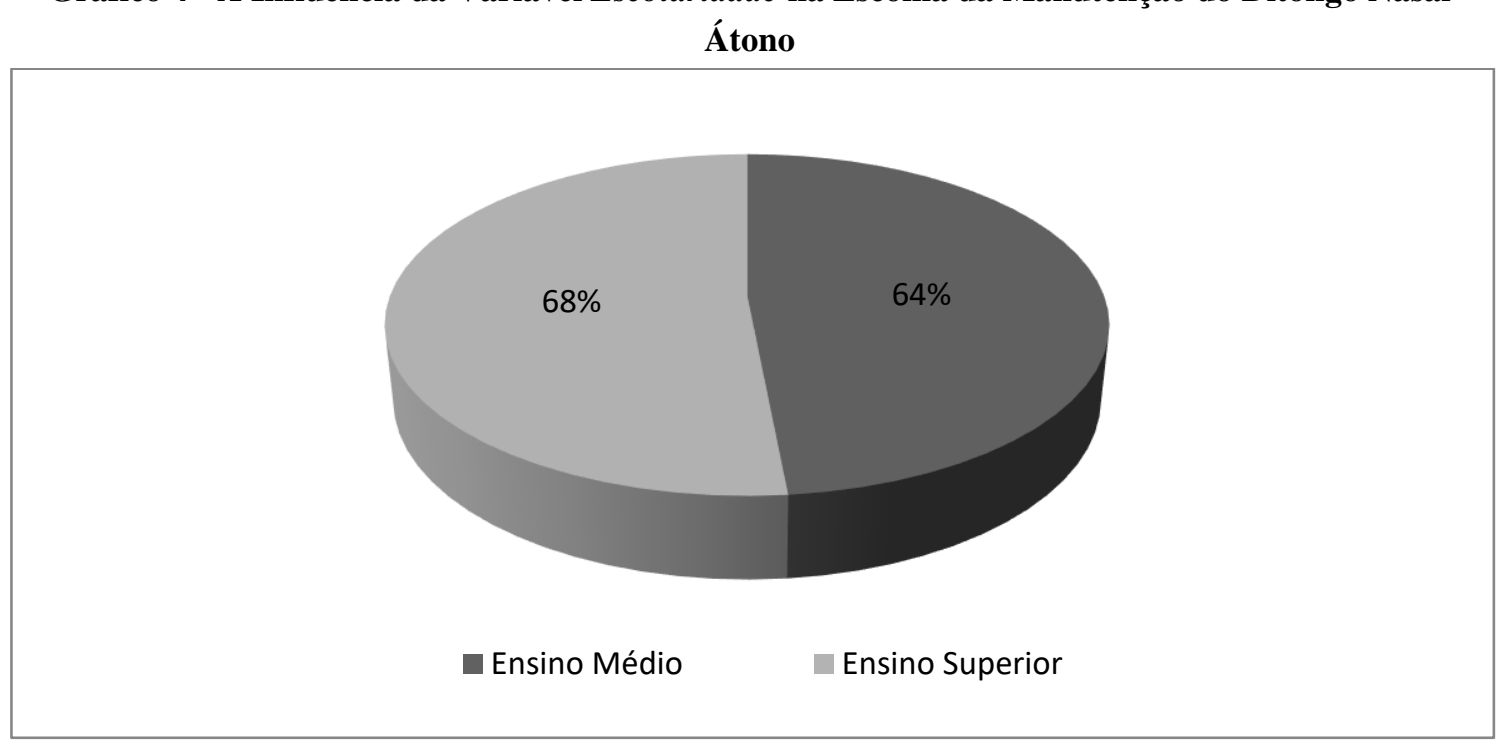

FONTE: elaborado pela autora.

Ao observarmos o gráfico percebemos que a diferença não é tão grande referente à Escolaridade, apresentando 64\% das ocorrências comprova-se que indivíduos com Ensino Médio tendem a desnasalizar o ditongo, enquanto $68 \%$ das ocorrências constatam que indivíduos com Ensino Superior propendem para a manutenção do ditongo nasal.

Tabela 5

\begin{tabular}{|l|l|l|l|}
\hline \multicolumn{4}{|c|}{ A Influência da Variável Escolaridade na Escolha da Manutenção do Ditongo Nasal Átono } \\
\hline ESCOLARIDADE & Aplic./ Total & $\%$ & PR \\
\hline Ensino Médio & $662 / 1028$ & $64 \%$ & .45 \\
\hline Ensino Superior & $560 / 825$ & $68 \%$ & .56 \\
\hline
\end{tabular}

Input: 0.688

Significância: 0.067

Ao analisarmos as ocorrências e os pesos relativos dos dados obtidos pode se verificar que os estudos sociolinguísticos são confirmados quando apresenta .56 


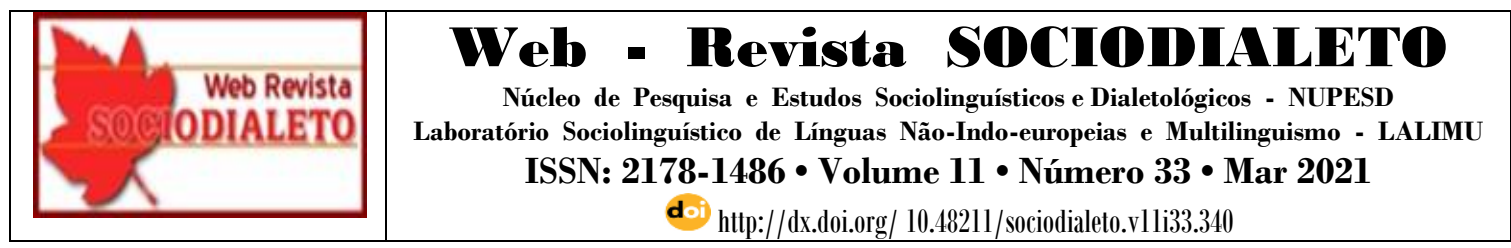

apresentando 560 de 825 ocorrências no Ensino Superior comprovando que os indivíduos com mais escolarização prezam pela não aplicação da regra ${ }^{14}$ optando por conservando o ditongo átono nasal, ao passo que aponta .45 com 662 de 1028 ocorrências no Ensino Médio validando que os indivíduos com menos escolarização tendem a eliminar o ditongo átono nasal, aplicando a regra e escolhendo a norma nãopadrão.

\subsection{A Influência da Variável Sexo na Escolha da Manutenção do Ditongo Nasal Átono}

Em seguida, foi apresentada a variável Sexo, mostrando os seguintes dados:

Gráfico 5 - A Influência da Variável Sexo na Escolha da Manutenção do Ditongo Nasal Átono

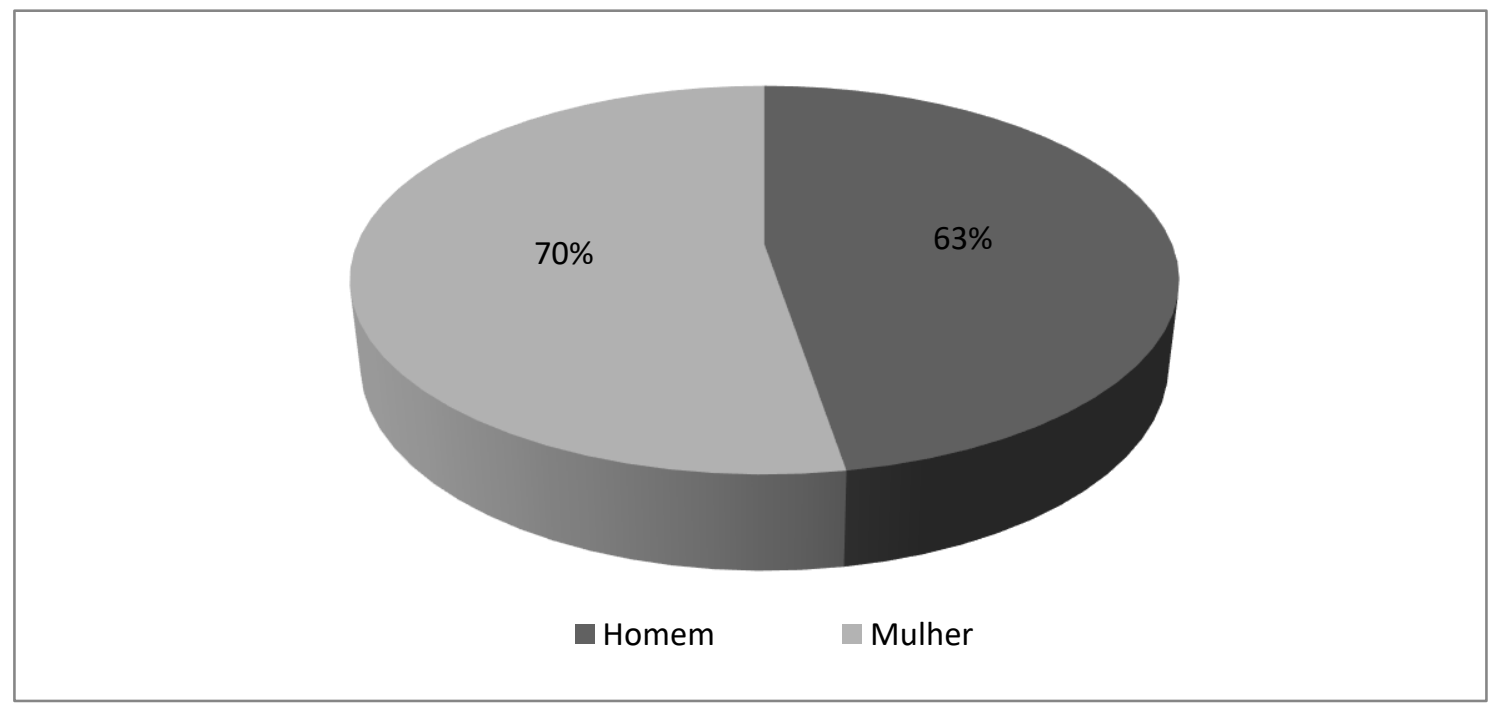

FONTE: elaborado pela autora.

Ao analisarmos o gráfico podemos reparar a proximidade em relação aos resultados, visto que os homens apontaram $63 \%$ das ocorrências, indicando que estes tendem a reduzir os ditongos átonos nasais, enquanto as mulheres marcam $70 \%$ das

\footnotetext{
14 A aplicação da regra aqui diz respeito à ocorrência do fenômeno, porém em minha codificação a aplicação da regra correspondeu à norma padrão.
} 


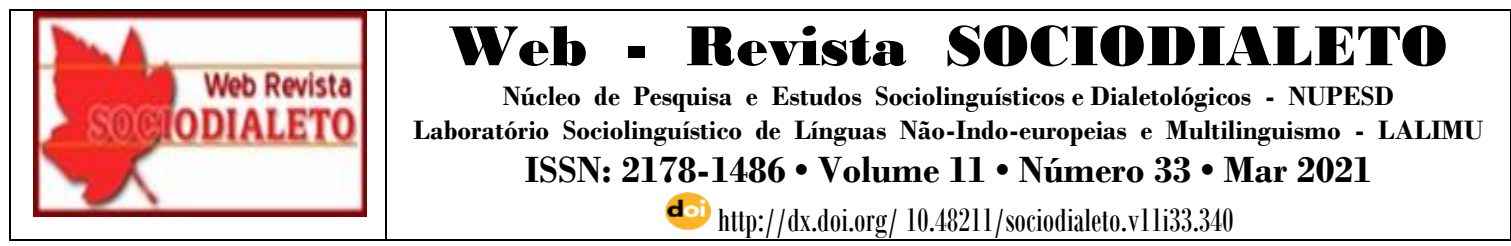

ocorrências propendendo à utilização da norma padrão, ou seja, a manutenção dos ditongos átonos nasais.

Tabela 6

\begin{tabular}{|l|l|l|l|}
\hline \multicolumn{4}{|c|}{ A Influência da Variável Sexo na Escolha da Manutenção do Ditongo Nasal Átono } \\
\hline SEXO & Aplic./ Total & $\%$ & PR \\
\hline Homem & $642 / 1023$ & $63 \%$ & .45 \\
\hline Mulher & $580 / 830$ & $70 \%$ & .55 \\
\hline
\end{tabular}

Input: 0.688

Significância: 0.067

De acordo com os dados acima apresentados comprovamos que .55 indicando 580 de 830 ocorrências produzidas pelas mulheres optam pela norma padrão, mantendo a nasalização do ditongo átono, e .45 apontando 642 de 1023 ocorrências produzidas pelos homens reafirmam que eles pendem a utilizar a norma não-padrão reduzindo o ditongo átono nasal assim como aponta os estudos sociolinguísticos. Pierre Bourdieu (2002, p. 71, Calvet) traz uma teoria acerca disso alegando que as mulheres optam mais pela norma padrão devido ao sistema machista imposto pelo patriarcado, devido a isso as mulheres comumente prezam pela docilidade e instituições como o casamento, a divisão de tarefas consideradas femininas e a tendência ao consumismo as levariam a utilizar mais a regra vigente.

Porém, para outros contextos de comunidade de fala Labov traz a contribuição de que em algumas sociedades a mulher está à frente do homem, sendo que elas desempenham papel social comercial, atuando mais na vida pública optando pela norma de prestígio (LABOV, 1981, p. 184), o que não acontece na comunidade de fala estudada.

\section{Variantes Irrelevantes}


Ao revisarmos os estudos que se referem à desnasalização das vogais postônicas podem perceber que as variáveis Contexto Fonológico Seguinte e Classe de Palavras são apontadas como significativas, sendo estudadas com aprofundamento nos estudos fonológicos por autores como BATTISTI (2000, 2002, 2003), SILVA, FONSECA \& CANTONI (2012) e BOPP \& SCHWINDT (2009), porém acredito que pelo motivo desses estudos se concentrarem no Sul e no Sudeste do Brasil e a nossa comunidade de fala se concentrar no Nordeste do Brasil os resultados saíram bem distintos apresentando pontos de relevância diferentes.

Dessa maneira, foram descartadas as variáveis Classe de Palavras e Contexto Fonológico Seguinte, que aos serem observados seus valores pode-se observar que são bem próximos não trazendo uma contribuição considerável para os estudos fonológicos.

Com isso, foram apresentados os seguintes resultados para Classe de Palavras:

Tabela 7

A Influência da Variável Classe de Palavras na Escolha da Manutenção do Ditongo Nasal Átono

\begin{tabular}{|l|l|l|}
\hline Classe de Palavras & Aplic./ Total & PR \\
\hline Substantivo & $521 / 826$ & $63 \%$ \\
\hline Verbo & $689 / 1009$ & $68 \%$ \\
\hline Adjetivo & $12 / 18$ & $67 \%$ \\
\hline
\end{tabular}

Input: 0.688

Significância: 0.067 .

Ao analisarmos os dados obtidos notados que $68 \%$ dos verbos tendem a manter os ditongos átonos nasais e $63 \%$ dos substantivos são propensos a desnasalar o ditongo nasal átono. É importante evidenciar que o estudo dos os advérbios foram retirados por ter havido apenas duas ocorrências que acusaram norma padrão.

Nos dados referidos ao Contexto Fonológico Seguinte, foram constatados os seguintes valores: 


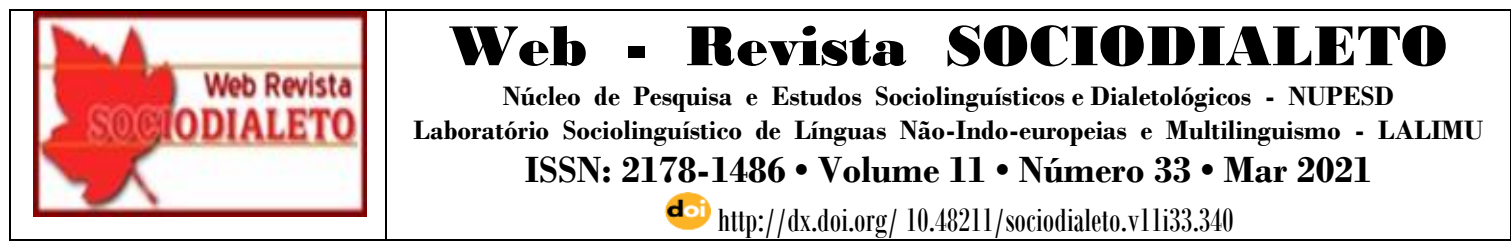

Tabela 8

\begin{tabular}{|c|c|c|}
\hline \multicolumn{3}{|l|}{ 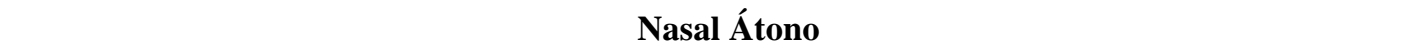 } \\
\hline $\begin{array}{ll}\text { CONTEXTO } & \text { FONOLÓGICO } \\
\text { SEGUINTE } & \end{array}$ & Aplic./ Total & $\%$ \\
\hline Consoante Nasal & $201 / 295$ & $68 \%$ \\
\hline Consoante Não-nasal & $548 / 815$ & $67 \%$ \\
\hline Vogal & 395 / 621 & $64 \%$ \\
\hline Sem Ocorrência do CFS & $78 / 122$ & $64 \%$ \\
\hline
\end{tabular}

Input: 0.688

Significância: 0.067

Foi observado que $68 \%$ das palavras com consoante nasal no contexto fonológico seguinte tendem a manter a nasalização, já em relação à desnasalização houve um empate as vogais e ao que foi denominado sem ocorrência do CFS possuindo $64 \%$ dos dados retidos.

\section{Considerações Finais}

Considerando as pesquisas variacionistas referentes à redução dos ditongos átonos nasais, podemos notar que houve uma enorme discrepância entre os dados apresentados pelos autores citados e os resultados obtidos nesta pesquisa, porém um fator observado que pode justificar isso diz respeito à maioria dos trabalhos terem sido desenvolvidos no sul do país, visto que os falares sulistas diferem muito dos "dialetos" nordestinos.

Tendo em vista comunidade de fala de Cachoeirinha - PE, uma cidade pequena, interiorana e de tradição enraizada ainda em costumes rurais, a expectativa foi quebrada quando acusou que $66 \%$ das ocorrências analisadas mantém o ditongo átono nasal, ao passo que apenas 34\% das ocorrências constataram desnasalização no ditongo átono nasal, mostrando que a população cachoeirinhense opta pela norma padrão da variante. 
$\mathrm{Na}$ análise de dados foi possível observar que as variáveis sociais (extralinguísticas ou externas) são predominantemente relevantes no estudo da variante em tela. Dessa forma, em pesquisas futuras pretendemos ampliar a análise do corpus com base em outras variáveis internas, sendo elas: tonicidade do contexto fonológico seguinte, tamanho do vocábulo e vogal do ditongo. Quanto ao contexto fonológico seguinte, essa variável será expandida já que foi analisada apenas a presença de nasalidade na consoante ou não, ou a presença da vogal, ao ampliarmos, vamos buscar analisar a natureza fonológica da consoante, identificando quais consoantes condicionam a redução ou a mantém, com isso cremos que essa variável ganhará relevância a partir dessa análise mais minuciosa.

O contexto fonológico precedente, comprovou que a consoante nasal tende a reduzir o ditongo átono nasal. Uma hipótese que pode ser levantada em relação a isso seria com base na grande quantidade de nasalidade em uma sílaba. Já que nasalidade presente na consoante do onset e no ditongo. Desse modo, para tornar a sílaba mais leve, tende-se a haver o fenômeno da denasalização, o qual eliminando o arquifonema /N/ ou o fonema [n], um exemplo de palavra exposta a essa regra seria homem ['õmẽ̃n] que se tornaria homi ['õmi] tornando a vogal nasal e a glide em uma vogal oral. Portanto, não pretendemos ampliar essa variável fonológica, já que as consoantes nãonasais não executaram nenhuma função significante em relação às duas normas da variante. Esses dados coincidem apenas com os resultados conseguidos por Bopp \& Schwindt (2009), que concentraram sua pesquisa no sul do Brasil, abrangendo os estados do Paraná e do Rio Grande do Sul. Acerca dessa variável Câmara Jr. (1981, pág. 350 apud. Battisti) e Guy (1981, pág. 35 apud. De Bona \& Schwindt) acentuam que as consoantes palatais anulam o ditongo, porém constatamos que no falar cachoeirinhense isso não acontece.

Em relação às variáveis sociais relevantes, pode se verificar que a idade se consagrou como a mais importante apontando que a faixa etária intermediária tende a desnasalizar os ditongos átonos nasais enquanto os mais jovens propendem a manter a nasalidade. Dessa forma, conclui-se que a variante em estudo não se configura como inovadora sendo aplicada aos mais velhos a partir de 31 anos. Apresentando resultados 
aproximados, a terceira variante de importância foi a escolaridade, confirmando os pressupostos sociolinguísticos de que quanto maior a escolarização mais os indivíduos de uma comunidade tendem a optar pela norma padrão, ao passo que os menos escolarizados optam pela norma não-padrão, o que favorece o uso do fenômeno de redução dos ditongos átonos nasais.

A última variante que indicou relevância foi o sexo. Mesmo apresentando valores aproximados, constatou-se que os homens tendem a aplicar a regra, ao passo que as mulheres escolhem a norma padrão, condizendo, assim, com os postulados sociolinguísticos, que supõem que isso aconteça por causa da sociedade patriarcal e machista que impõe às mulheres o uso da norma padrão.

Dessa forma, podemos chegar à conclusão de que é um fenômeno estigmatizado, visto que é utilizado apenas pelas classes tidas como subalternas na sociedade, pessoas com mais de 31 anos e com pouca escolaridade, exceto os homens, não sendo uma variante inovadora.

Postas as considerações, acreditamos que este trabalho deve ser continuado considerando como fator extralinguístico localização geográfica, já que cada comunidade de fala possui seus traços e regras linguísticas próprias. Desse modo, seriam incluídas cidades maiores com populações mais numerosas.

Com isso, acredito que esta pesquisa auxilia os estudos sociolinguísticos e fonético-fonológicos, uma vez que não foram encontradas pesquisas em Pernambuco. Das encontradas, somente três referem-se a descrições do fenômeno no Nordeste (MIRANDA, 2017; PEDROSA, 2014; MENDONÇA, DIAS E OLIVEIRA, 2017).

Portanto, essa pesquisa pode ser expandida para cidades maiores circunvizinhas, que possuem outro contexto em relação aos seus costumes e socialização que podem influenciar muito nos resultados, já que todas as variáveis externas foram significativas.

\section{Referências}

BATTISTI, Elisa. A Nasalização do Português Brasileiro e a Redução dos Ditongos Nasais Átonos: Uma Abordagem Baseada em Restrições. 1997. Tese (Doutorado) - 
Pontifícia Universidade Católica do Rio Grande do Sul, Porto Alegre. http://leffa.pro.br/tela4/Textos/Textos/Teses/Elisa_Batisti.pdf.

BATTISTI, Elisa. A Perda de /N/ em Ditongos Nasais Átonos. Porto Alegre: Letras de Hoje. V. 38. $\mathbf{n}^{\circ}$ 4. p. 347-357. dez, 2003.

BATTISTI, Elisa. A Redução dos Ditongos Nasais Átonos. In: BISOL, Leda. Brescancini, Cláudia (Org.). Fonologia e variação; recortes do português brasileiro. Porto Alegre: $\quad$ EDIPURS, $2002 . \quad$ p. $183-202$. https://books.google.com.br/books?id=V51ihhlkiGMC\&pg=PP1\&lpg=PP1\&focus=vie wport\&hl=pt-BR\&output=html_text.

BATTISTI, Elisa. A Redução Variável dos Ditongos Nasais Átonos no Português do Sul do Brasil. Letras de Hoje. Porto Alegre. V. 35. n 1. p. 255-274. Mar, 2000. https://revistaseletronicas.pucrs.br/ojs/index.php/fale/article/view/14767/9833.

BISOL, Leda. Introdução a estudos de fonologia do português brasileiro. 3. edição. Porto Alegre: EDIPUCRS, 2001.

BONA, Camila de. SCHWINDT, Luiz Carlos. O papel da frequência lexical na desnasalização do ditongo final átono[ẽ̃̃n] em não verbos no português do sul do Brasil. Cadernos do IL, Porto Alegre, n. ${ }^{\mathbf{0}}$ 54, out, 2017 . p. 27-46. https://www.lume.ufrgs.br/handle/10183/170121.

BOPP DA SILVA, Taís. A Redução da Nasalidade em Ditongos de Sílaba Átona em Final de Vocábulo entre Falantes Bilíngues e Monolíngues no Rio Grande do Sul. 2005. Dissertação (Mestrado) - Universidade Federal do Rio Grande do Sul, Porto Alegre. https://lume.ufrgs.br/handle/10183/4596.

CALVET, Louis-Jean. Sociolinguística: Uma Introdução Crítica. São Paulo: Parábola, 2002.

CHAVES, Raquel Gomes. A Redução/ Desnasalização de Ditongos Nasais Átonos Finais e a Marcação Explícita de CVP6: Um Estudo de Correlação. 2017. Tese (Doutorado) - Universidade Federal de Santa Catarina, Florianópolis. https://repositorio.ufsc.br/xmlui/handle/123456789/182738.

COLLISCHONN, G. Proeminência Acentual e Estrutura Silábica: Seus Efeitos em Fenômenos do Português Brasileiro. In: ARAÚJO, Gabriel Antunes de. ABAURRE, Berdanete (Orgs.). O Acento de Português: Abordagens Fonológicas. São Paulo. Parábola, 2007. p. 195-223.

DE MENDONÇA, Ana Maria Santos; DIAS, Crislani da Silva; DE OLIVEIRA, Alan Jardel. Monotongação de ditongos nasais finais átonos em Maceió/AL. LETRÔNICA, $\begin{array}{llll}\text { v. } 10, & \text { p. } & 265-277, & \end{array}$ https://revistaseletronicas.pucrs.br/index.php/letronica/article/view/25057.

LABOV, W. Padrões sociolinguísticos. Trad. Marcos Bagno, Maria Marta Pereira Scherre, Caroline Rodrigues Cardoso. São Paulo: Parábola, 2008 [1972].

LEE, Seung Hwa. O Acento Primário em Português: Uma Análise Unificada na Teoria da Otimalidade. In: ARAÚJO, Gabriel Antunes de. ABAURRE, Berdanete (Orgs.). O 


\begin{tabular}{|c|c|}
\hline $\begin{array}{r}\text { Web Revista } \\
\text { ODIALETO }\end{array}$ & $\begin{array}{c}\text { Núcleo de Pesquisa e Estudos Sociolinguísticos e Dialetológicos - NUPESD } \\
\text { Laboratório Sociolinguístico de Línguas Não-Indo-europeias e Multilinguismo - LALIMU } \\
\text { ISSN: } 2178-1486 \bullet \text { Volume } 11 \bullet \text { Número 33 } \text { Mar 2021 } \\
\text { doi http://dx.doi.org / } 10.49211 / \text { sociodialeto.vlli33.340 }\end{array}$ \\
\hline
\end{tabular}

Acento de Português: Abordagens Fonológicas. São Paulo. Parábola, 2007. p. 121143.

MIRANDA, Wânia. A Concordância Verbal nas Comunidades Quilombolas de Alcântara (MA): Uma Constituição para a Discussão sobre o Contato Linguístico no Português Brasileiro. 2017. Tese (Doutorado) - Faculdade de Filosofia, Letras e Ciências Humanas na Universidade de São Paulo. São Paulo. https://teses.usp.br/teses/disponiveis/8/8139/tde-06022018-124834/pt-br.php.

PEDROSA, L. M.. A desnasalização de ditongo nasal final de formas verbais. In: Grupo de estudos linguísticos e literários do Nordeste - GELNE, 2014, Natal. Anais da XXV Jornada Nacional do GELNE. Natal - RN: Editoração Eletrônica, 2014. v. 25. http://gelne.com.br/arquivos/anais/gelne-2014/anexos/339.pdf.

SCHWINDT, Luiz Carlos. BOPP DA SILVA, Taís. Panorama da Redução da Nasalidade em Ditongos Átonos Finais no Português do Sul do Brasil. In: BISOL, Leda. COLLISHONN, Gisela (Orgs.). Português do sul do Brasil: variação fonológica. Porto Alegre: $\quad$ EDIPUCRS, $2009 . \quad$ p. $13-33$. https://editora.pucrs.br/edipucrs/acessolivre/livros/portuguesdosuldobrasil.pdf.

SILVA, Marlon Miranda da. Aspectos fonológicos e morfológicos da fala do Quilombo do Curiaú, Amapá, Brasil. 2016. Tese (Doutorado) - Vrije Universiteit de Amsterdam. https://docplayer.com.br/57803263-Aspectos-da-fonologia-e-damorfologia-da-fala-do-quilombo-do-curiau-amapa-brasil.html.

SILVA, Thaïs Cristófaro. Fonética e Fonologia do Português: Roteiro de Estudos e Guia de Exercícios. 11. edição. São Paulo: Contexto, 2017.

SILVA, Thaïs Cristófaro; FONSECA, Marco Silva; CANTONI, Maria. A redução do ditongo [ãw] postônico na morfologia verbal do português brasileiro: uma abordagem baseada no uso. Letras de Hoje, Porto Alegre, v. 47, n. 3, p. 283-292, jul./set. 2012. http://journaldatabase.info/articles/reducao_ditongo_\%5Baw_postonico_na.html.

Recebido em: 23/10/2020 | Aprovado em: 10/01/2021. 